Article

\title{
Glycosylated Metal Phthalocyanines ${ }^{\dagger}$
}

\section{Michael Hanack}

Received: 11 August 2015 ; Accepted: 16 October 2015 ; Published: 10 November 2015

Academic Editor: Giuseppe Mele

Institut für Organische Chemie der, Universität Tübingen, Auf der Morgenstelle 18, 72076 Tübingen,

Germany; hanack@uni-tuebingen.de; Tel.: +49-7071-297-2432; Fax: +49-7071-295-268

$\dagger$ Dedicated to Professor Tomas Torres on the occasion of his 65th birthday.

Abstract: In the first part; the syntheses of mono-; di-; and tetra-glycosylated phthalonitriles is described; which are the most used starting materials for the preparation of the corresponding glycosylated metal (mostly zinc) phthalocyanines. In the second section; the preparation of symmetric and unsymmetric mono-; tetra-; and octa- glycosylated zinc phthalocyanines are reviewed; in which the sugar is attached to the phthalocyanine macrocycle; either anomerically or via another one of its $\mathrm{OH}$-groups.

Keywords: phthalonitriles; phthalocyanines; glycosylation

\section{Introduction}

Phthalocyanines (Pcs), (Figure 1), PcM metal phthalocyanines and naphthalocyanines (Ncs), respectively, are macrocyclic compounds which are structurally related with porphyrins and porphyrazines. Phthalocyanines, although not found in nature, have resemblance with naturally-occurring substances, such as hemoglobin, vitamin $\mathrm{B}_{12}$, and chlorophyll. Phthalocyanines have found many applications in various fields [1-5].

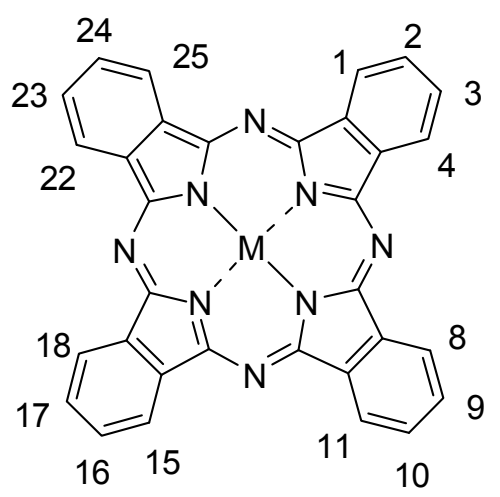

PcM

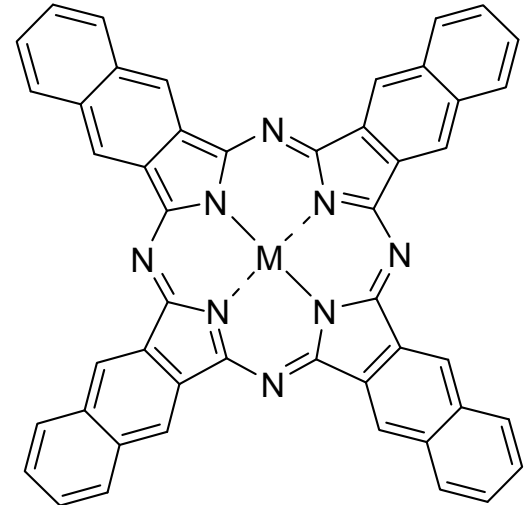

2,3-NcM

Figure 1. Structures of PcM and 2,3-NcM.

Phthalonitriles and substituted phthalonitriles are the most widely used starting materials for the synthesis of metal free and metal phthalocyanines. Substituted Pcs are generally synthesized from the corresponding substituted phthalonitriles. As an example, tetrasubstituted Pcs are obtained as a mixture of four constitutional isomers $\left(C_{2 v}, C_{4 h}\right.$, etc.) (Figure 2) by tetramerization of e.g., 3-substituted phthalonitriles. 

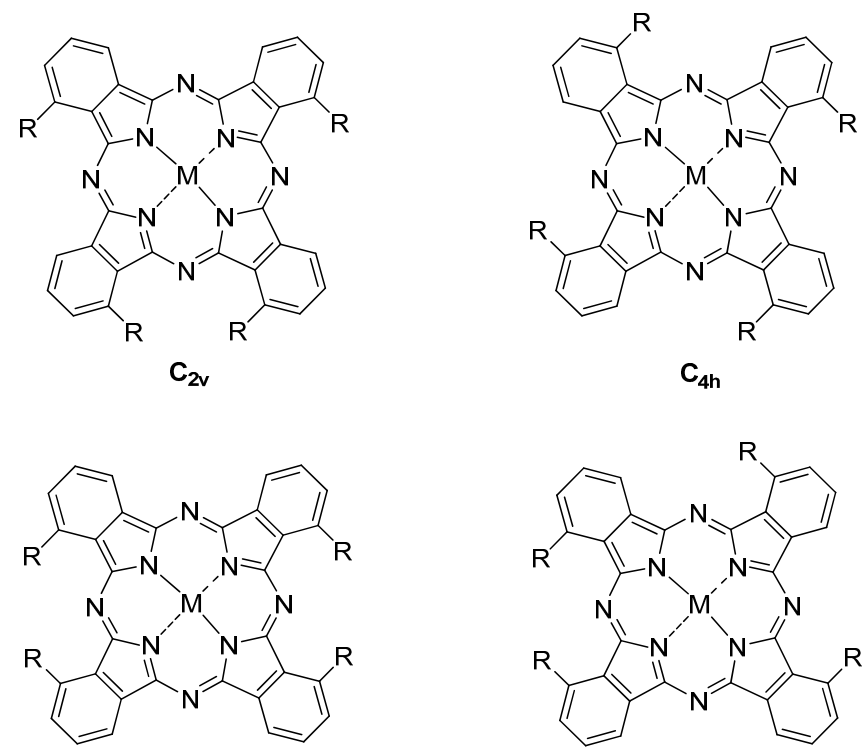

$D_{2 h}$

$\mathrm{C}_{\mathrm{s}}$

Figure 2. Constitutional isomers of tetrasubstituted metal phthalocyanines.

Separation of the isomers of substituted Pc was first achieved by Hanack and coworkers using high-performance liquid chromatography (HPLC) [3,5].

The solubility of phthalocyanines in common organic solvents is low but can be increased by introduction of bulky or long chain substituents in the periphery of the macrocycle and/or by axial ligand substitution of an appropriate central metal e.g., $\mathrm{Si}, \mathrm{Ge}$, or with central metals like $\mathrm{Fe}$ or $\mathrm{Ru}$ with coordinating axial ligands (axial substitution) [2-11]. For a discussion of the spectral properties of Pcs see ref. [2,4]. Phthalocyanines have first found use as dyes and pigments, however, more recently they have been employed in a variety of high-tech fields, e.g., as semiconductors, in photovoltaic solar cells, electrophotography, rectifying devices, molecular electronics, Langmuir-Blodgett films, liquid crystals, very intensively in nonlinear optics (optical limiting), photodynamic reagents for cancer therapy (PDT), and other medical applications $[9,10,12-15]$.

In 1985 Ben-Hur et al. [12] showed that some Pcs can photosensitize inactivation of mammalian cells. The ability of Pcs to act as second generation photosensitizers is due to the long wavelength band around $600-750 \mathrm{~nm}$ with large extinction coefficients. The presence of diamagnetic metals e.g., $\mathrm{Zn}, \mathrm{Al}, \mathrm{Ga}$ etc. in the Pc core enhance the photo activity due to a long-lived triplet state, leading to the generation of higher concentration of singlet oxygen $\left({ }^{1} \mathrm{O}_{2}\right)$, with quantum yields of $0.18-0.62$ [16-19]. However, the low solubility and high aggregation tendency of phthalocyanines in aqueous medium leads to a decrease in the excited singlet states by internal conversion [16-19]. Our group has worked for many years on the synthesis and applications of metal phthalocyanines.

The interest for glycosylated metal phthalocyanines was stimulated by comparing the extensive work on glycosylated porphyrins with the almost unknown phthalocyanine counterparts and their application in PDT. It was assumed that the presence of carbohydrate substituents in Pcs would increase their solubility in aqueous media, their membrane activity and, thereby, increase their tumor selectivity when applied in PDT.

Carbohydrate substituted pthalocyanines were not known until 1989, when Maillard et al. published the first paper on a glucofuranose substituted PcZn [20]. For details see page 5. Since 2006 when Hanack, Ziegler et al. [21] prepared the first anomerically-substituted zinc phthalocyanines, additional glycosylated metal Pcs and Ncs were synthesized by our and other groups. 
The most common starting materials for the syntheses of glycosylated phthalocyanines are glycosylated phthalonitriles.

\section{Glycosylated Phthalonitriles}

A well-known reaction for the preparation of phthalonitriles is the cyano-dehalogenation process (Rosenmund von Braun reaction) [22] in which 1,2-dibromobenzenes are reacted with cuprous cyanide in refluxing DMF. Hanack and co-workers proposed an even easier method to prepare substituted phthalonitriles from substituted catechols via their corresponding aryl bistriflates [23]. They also developed a palladium-catalyzed cyanation of mono- and disubstituted $o$-dibromobenzenes to obtain the corresponding phthalonitriles [24]. A few examples for the synthesis of mono- and polyglycosylated phthalonitriles will be given: by $\mathrm{S}_{\mathrm{NAr}}$ displacement of $\mathrm{NO}_{2}$-groups monoglycosylated phthalonitriles e.g., 4 or $\mathbf{5}$ with various sugar molecules were synthesized [20,21] by nitrite substitution in 4- or 3-nitrophthalonitriles $\mathbf{1}$ and $\mathbf{2}$ with anomerically-deprotected glycosides and thioglucosides in DMF or DMSO, while $\mathrm{NaH}$ or $\mathrm{K}_{2} \mathrm{CO}_{3}$ was used as base [25-28] (Scheme 1).<smiles>N#Cc1ccc([N+](=O)[O-])cc1C#N</smiles>

1,2
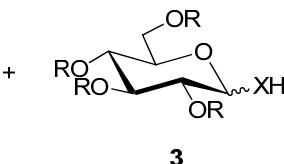

3

$\mathrm{X}=\mathrm{O}, \mathrm{S}$

$R=$ benzyl, benzoyl, acetyl

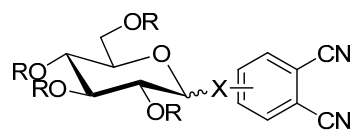

4, 5

Scheme 1. Glycosylation reaction between 3- or 4-nitrophthalonitriles $(\mathbf{1}, \mathbf{2})$ and glycopyranoses (3).

In glycosylated phthalonitriles 6 and 7 the sugar units are linked to the phthalonitrile fragment by a hydroxyl group located at carbon C-6 of the glycoside [27-31]. 6 and 7 were synthesized by nucleophilic displacement of nitro groups in the 4- or 3-nitrophthalonitriles 1, 2 with the corresponding sugars.

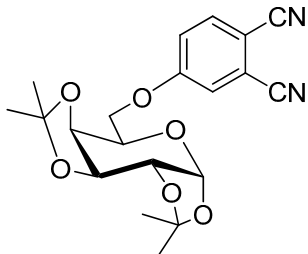

6

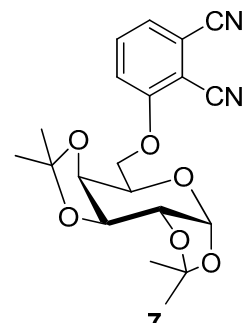

7

4,5-Diglycosylated phthalonitriles e.g., 10 were prepared for the first time by Hanack, Ziegler, and coworkers (Scheme 2) [32] from 4,5-difluorophthalonitrile (9b) and anomerically-deprotected sugars, using $\mathrm{K}_{2} \mathrm{CO}_{3}$ as base.

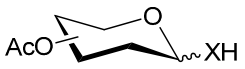<smiles>[R]c1cc(C#N)c(C#N)cc1[R]</smiles>

$9 \mathrm{a}=\mathrm{R}_{1}=\mathrm{Br}, \mathrm{R}_{2}=\mathrm{NO}_{2}$

$\mathrm{X}=0, \mathrm{~S}$ $9 b=R_{1}=R_{2}=F$

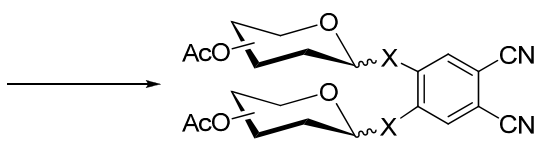

10
$X=0, s$

Scheme 2. Synthesis of 4,5-diglycosylated phthalonitriles 10.

4,5-Diglycosylated phthalonitriles, in which two galactose units connected via carbon-6, were also synthesized using the same method [30,33-35]. Several attempts for the connection of a carbohydrate residue in the positions 3 and 6 of phthalonitrile were published by 
Hanack, Ziegler et al. recently (Scheme 3) [36]. First 3,6-bis (triflyl) phthalonitrile (11) was reacted with 1,4-bis(1,2,3,4-di-O-isopropylidene- $\alpha$-D-galactopyranose (12) in DMF to give 1,4-bis(1,2:3,4-di-O-isopropylidene- $\alpha$-D-galactopyranos-6-yl)-phthalonitrile (13) in a yield of $17 \%$. Next 13 was also synthesized by nucleophilic displacement of two fluorine atoms in 3,6-difluorophthalonitrile (14) with galactopyranose 12 and $\mathrm{NaH}$ in toluene (yield 37\%). Finally, 2,3-dicyanohydroquinone (15) dissolved in toluene was reacted under Mitsunobu conditions (diethylazodicarboxylate, triphenylphosphine) to give sugar phthalonitrile 13 in $46 \%$ yield.

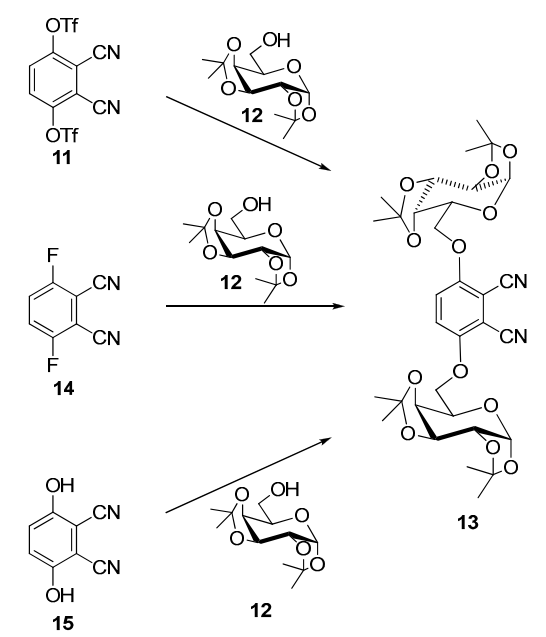

Scheme 3. Different methods for the synthesis of 3,6-substituted phthalonitriles.

Nucleophilic substitution of four fluorine atoms in tetrafluorophthalonitrile (16) by 1,2:3,4-di-O-isopropylidene- $\alpha$-D-galactopyranose units (12) gave the corresponding tetraglycosylated phthalonitrile 17 (Scheme 4) [33].

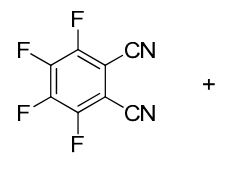

16

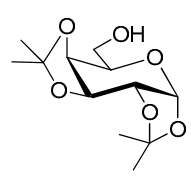

12

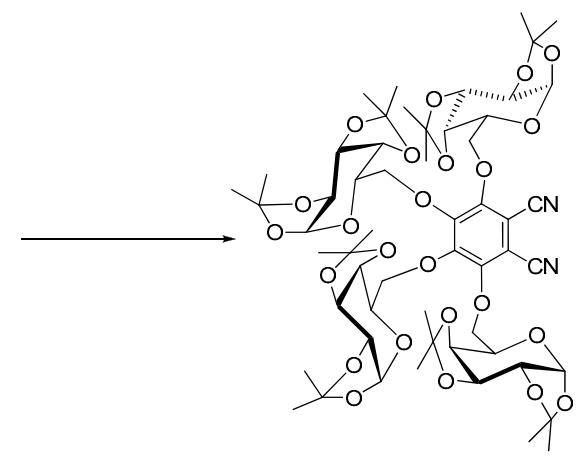

17

Scheme 4. Synthesis of tetrakis (1,2,3,4-di-O-isopropylidene- $\alpha$-D-galactopyranose-6-yl)phthalonitrile (17).

Only one example of a glycosylated naphthalonitrile $\mathbf{1 8}$ is reported by the group of Hanack and Ziegler [37].

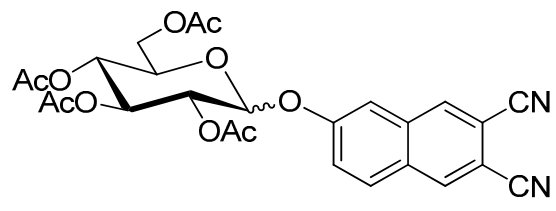




\section{Glycosylated Phthalocyanines}

The carbohydrate substituents can be attached to the Pc (or Nc) macrocycle through a glycosidic (anomeric) bond with a specific anomeric configuration, as a mixture of anomeric configurations or via one of its other functional groups. In addition the carbohydrate substituents can be attached to the macrocycle either in the $\alpha$ - or $\beta$-configuration, generating many isomers, which are difficult to separate in pure form.

Tetrasubstituted Pcs form four constitutional isomers (see Figure 2).

The first carbohydrate-substituted zinc(II) phthalocyanine 19 in which the sugar is linked via a non-anomeric bond was reported in 1989 by Maillard et al. [20] and later by $\mathrm{Ng}$ et al. [26].

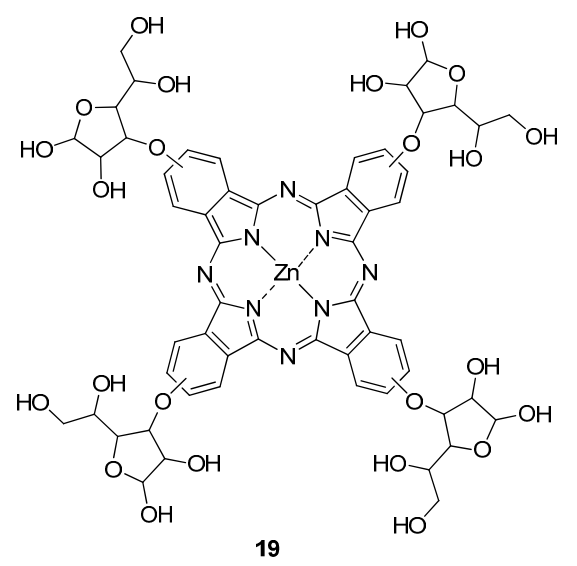

The first anomerically-glucosylated zinc(II) phthalocyanine 21 was synthesized 2006 by Hanack, Ziegler et al. as shown in Scheme 5 [21]. Hanack, Ziegler, and co-workers then, in 2006, developed a general method for the synthesis of anomeric tetra carbohydrate substituted PcZns 21 starting with corresponding phthalonitriles $\mathbf{2 0}$ in which sugar moieties such as glucose, galactose, maltose, thioglucose, and thiogalactose, are attached at $\beta$-position of the Pc macrocycle (Scheme 5) [28].

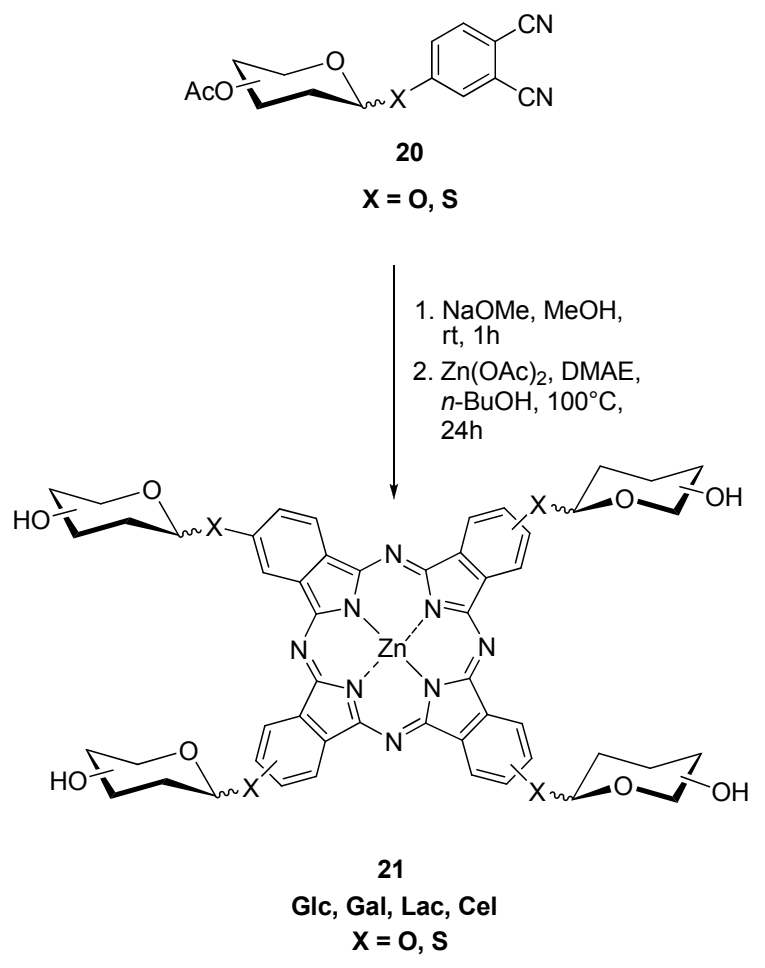

Scheme 5. Synthesis of anomerically-glycosylated zinc(II) phthalocyanines 21. 
Additionally, tetraglycosylated PcZns 22 with the substituents at the $\alpha$-position of the phthalocyanine ring were prepared by the same authors. As sugar substituents glucose, galactose, maltose, cellobiose, and lactose containing $\mathrm{O}$ or $\mathrm{S}$ atoms at anomeric position were selected [38].

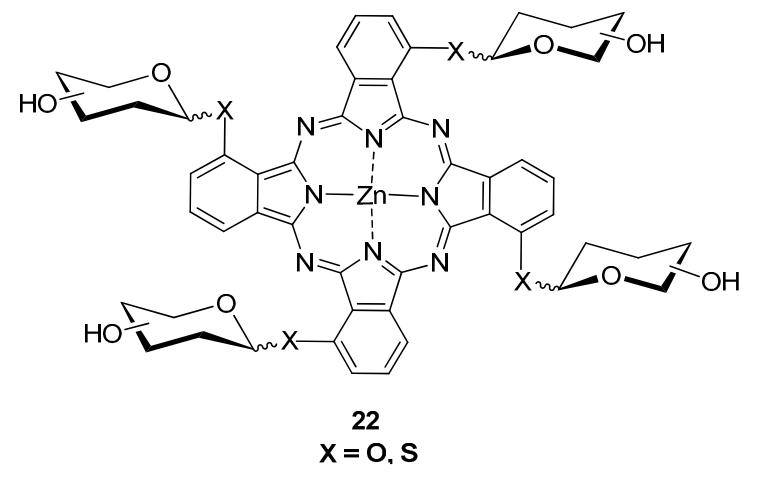

The syntheses of the anomeric octaglycosylated phthalocyanines $\mathbf{2 3 a} \mathbf{a}-\mathbf{i}$ and $\mathbf{2 4 a} \mathbf{a} \mathbf{i}$, respectively, (Scheme 6) turned out to be rather difficult; several methods had to be applied before a successful route could be found [32].

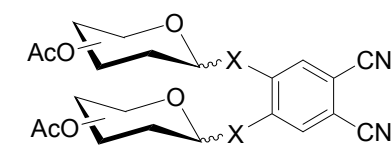

10 a-i

Glycoses

$\mathbf{a}=$ Glucose

b = Glucose

c = Galactose

d = Galactose

e = Lactose

f = Lactose

$\mathbf{g}=$ Cellubiose $\mathbf{O}$

$\mathbf{h}=$ Cellubiose $\mathbf{S}$

i = Maltose

\section{(a)}
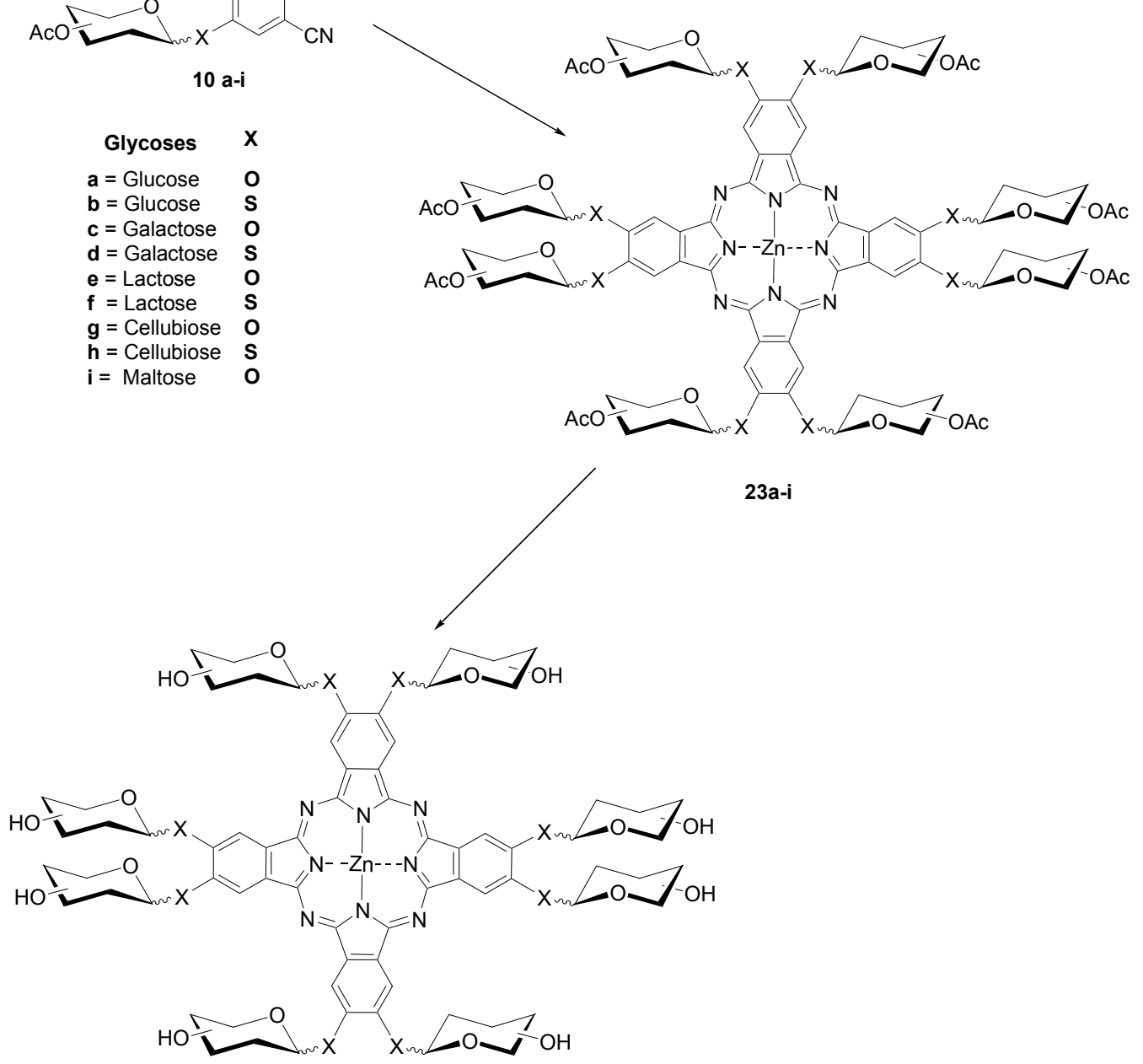

24a-i

Scheme 6. Synthesis of octaglycosylated zinc (II) phthalocyanines 24. 
After several attempts using a variety of conditions 10a was heated in DMF with $30 \mathrm{~mol} \%$ hexamethyldisilazane (HMDS), $p$-toluenesulfonic acid and $\mathrm{Zn}(\mathrm{OAc})$ at $125-130{ }^{\circ} \mathrm{C}$ overnight $[34,35]$. Using this procedure the octaglycosylated phthalocyanines 23a-i were obtained then in yields between $55 \%$ and $78 \%$ and deprotected to form the PcZns 24a-i [32,34,35]. 24a-i gave high triplet quantum yields ranging from 0.68 to 0.88 [39]. Attempts to cyclize compound 25 under various conditions which had been previously found suitable [21,29,31] failed. Therefore, 25 was first transformed into the isoindoline 26 [34,35] which could be converted into PcZn 27 in $29 \%$ yield as a green amorphous solid. Deprotection of the sixteen isopropylidene groups in $\mathbf{2 7}$ was achieved by treating it with aqueous trifluoroacetic acid. The obtained PcZn 28 is highly soluble in water (Scheme 7).

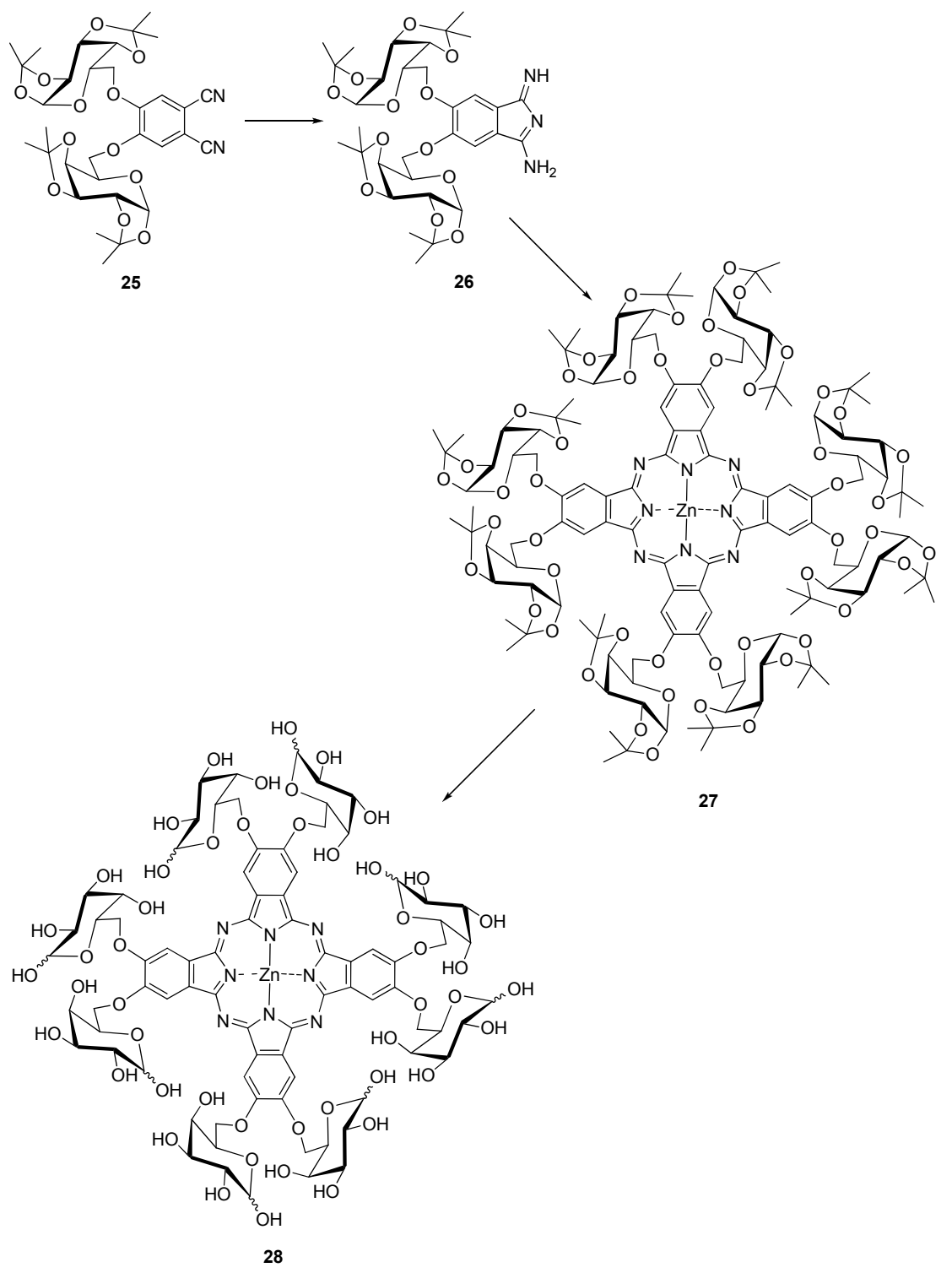

Scheme 7. Synthesis of octa-substituted galactose zinc(II) phthalocyanine 28.

A number of other glycoconjugated zinc(II) phthalocyanines were also studied by Torres and $\mathrm{Ng}$, respectively, concerning their effectiveness in PDT [25,26,29-31,33].

By condensation of 1,4-bis(1,2:3,4-di-O-isopropylidene- $\alpha$-D-galactopyranos-6-yl)-phthalonitrile (13) with an excess of phthalonitrile (29) and zinc bromide $22 \%$ of [1,4-bis(1,2:3,4-di-O- 
isopropylidene- $\alpha$-D-galactopyranos-6-yl)-phthalocyaninatolzinc(II) (30) was obtained which was deprotected to form 31 [36] (Scheme 8).

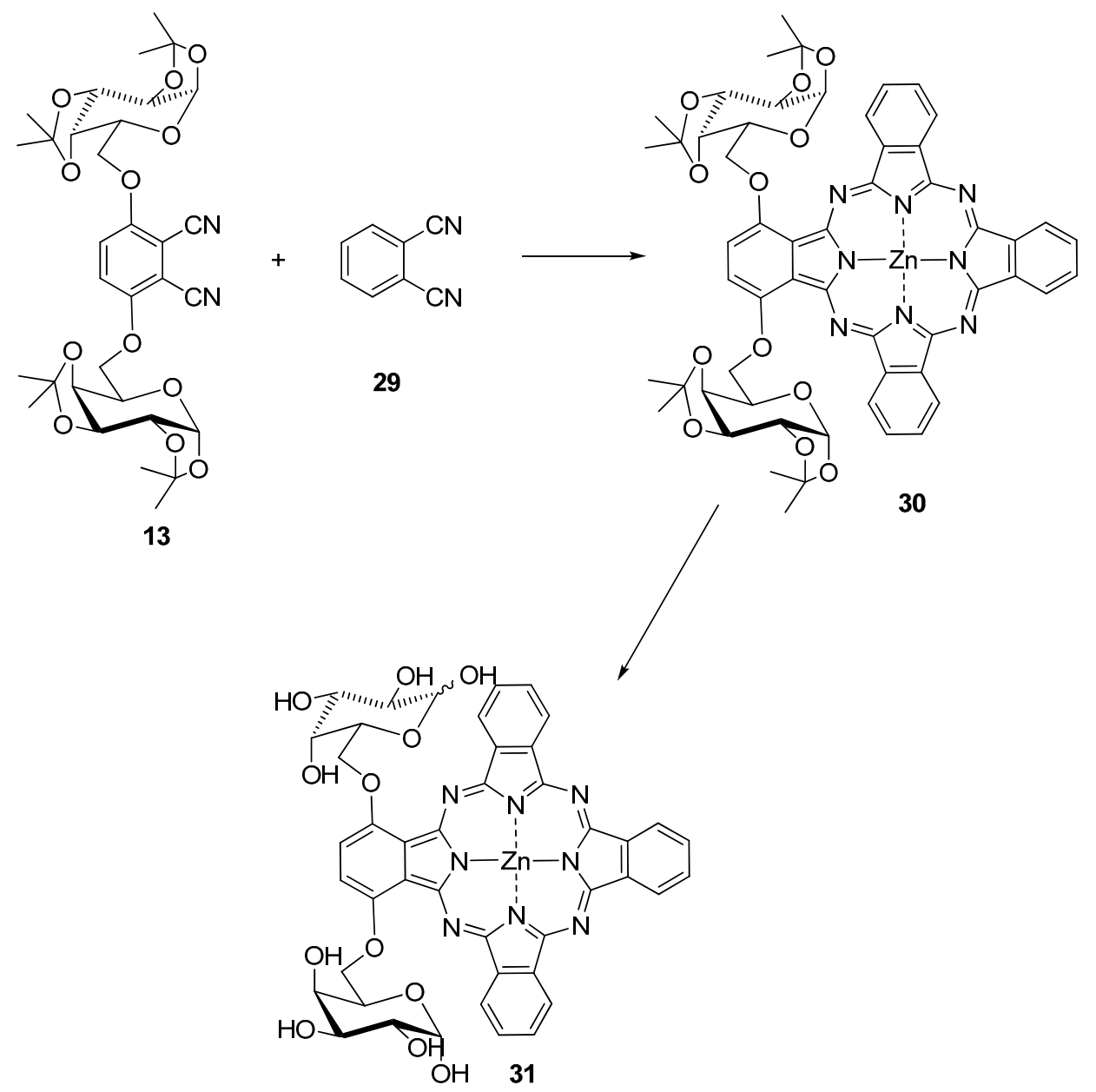

Scheme 8. Synthesis of the unsymmetric Pc 31.

Another water soluble unsymmetrical phthalocyanine 32. was synthesized by condensation of tetrakis(1,2:3,4-di-O-isopropylidene- $\alpha$-D-galactopyranos-6-yl)phthalonitrile with phthalonitrile and zinc(II) acetate and subsequent deprotection of the isopropylidene groups [33].

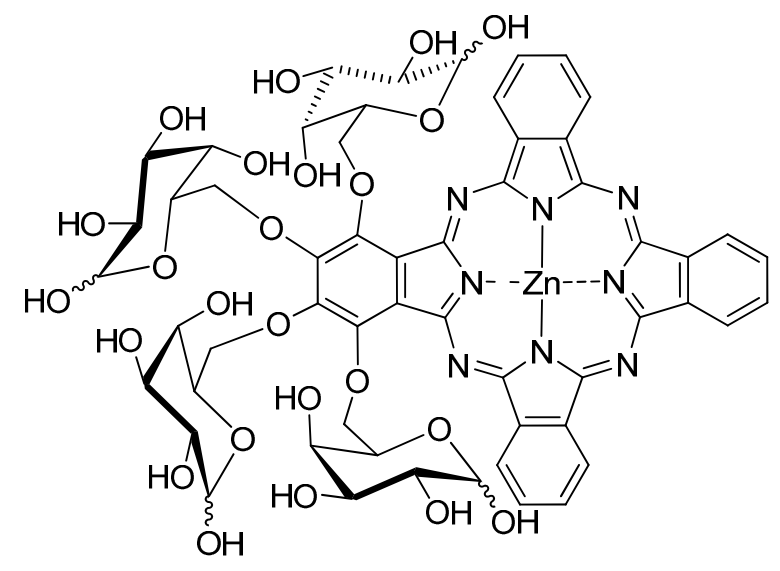


Starting from the corresponding substituted phthalonitriles other water soluble unsymmetrical mono 33, 34, and tetra-glycosylated phthalocyanines 35, 36 with sugar units linked by the hydroxyl group located at carbon C-6 were synthesized [26].

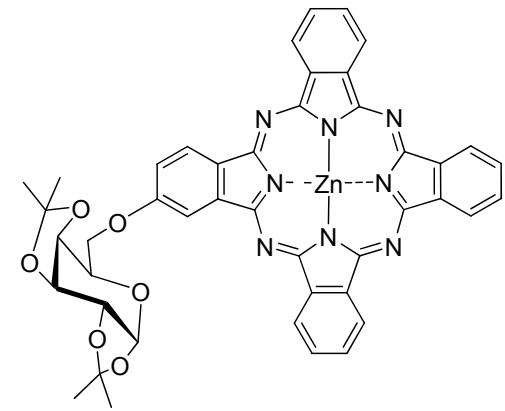

33

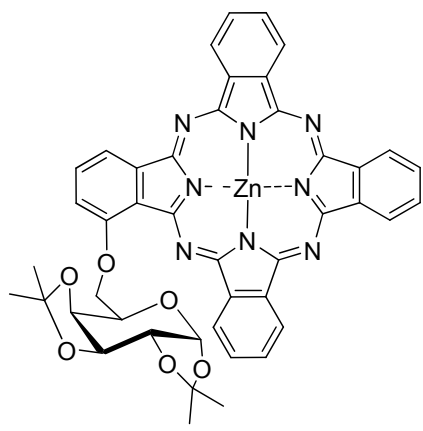

34

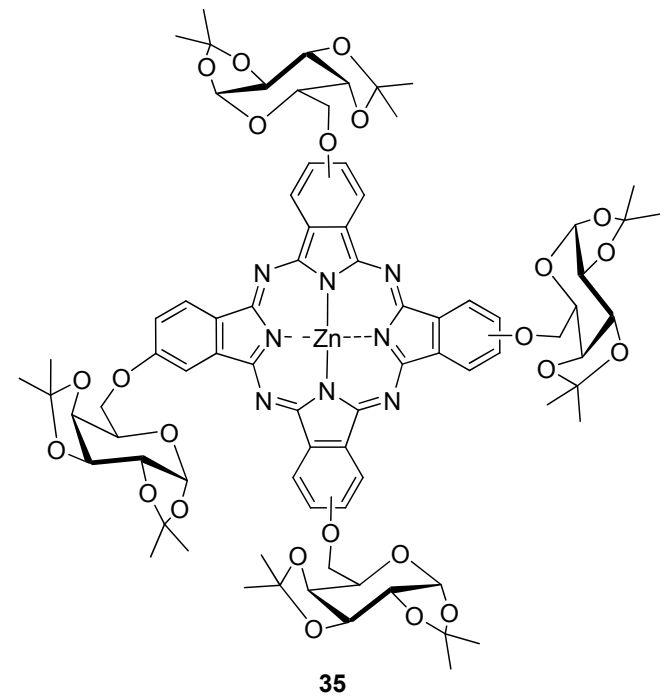

35

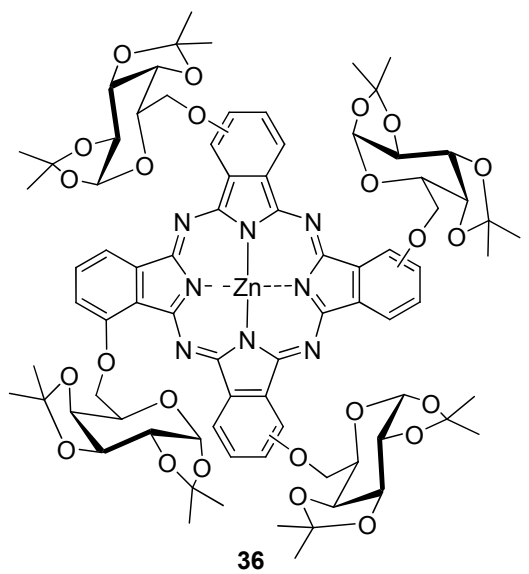

Protected zinc(II) phthalocyanines 33-36 were not significantly aggregated in organic solvents, giving a weak to moderate fluorescence emission. Upon irradiation 33-36 sensitize the formation of singlet oxygen in DMF, with quantum yields in range of $0.40-0.66$. The in vitro PDT activities of these zinc(II) phthalocyanines against HepG2 human hepatocarcinoma and HT29 human colon adenocarcinoma cells were also studied. The mono-glycosylated phthalocyanines 33, 34 show significantly higher photocytotoxicity compared with the tetra- $\alpha$-glycosylated analogues 35, 36, exhibiting $\mathrm{IC}_{50}$ values down to $0.9 \mu \mathrm{M}$ [26].

The octa-substituted galactose zinc(II) phthalocyanines 38, 39 have been reported by Torres et al. (Scheme 9) [30].

A series of silicon(IV) phthalocyanines with one or two axial acetal-protected galactose substituent(s) e.g., $\mathbf{4 1}$ have been prepared by $\mathrm{Ng}$ et al. starting with dichlorosiliconphthalocyanine 40 (Scheme 10) [40-42].

The future experimental work in our laboratory will concentrate on the synthesis of water soluble naphthalocyanines. 


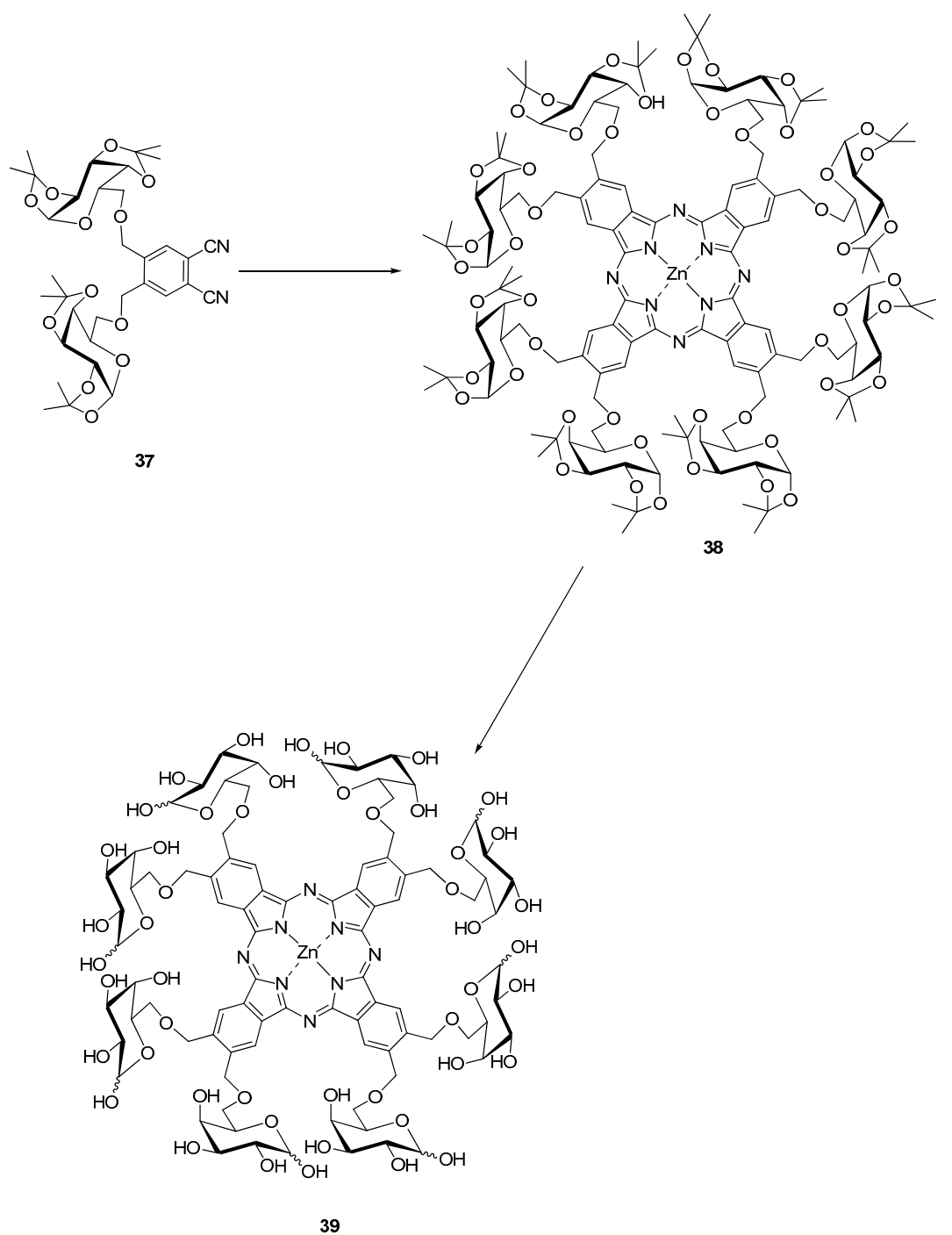

Scheme 9. Synthesis of octa-substituted galactose zinc(II) phthalocyanine 39.
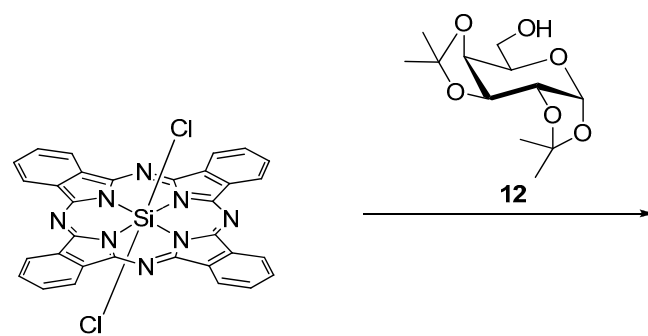

40

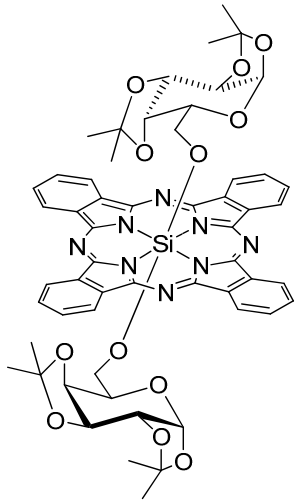

41

Scheme 10. Synthesis of PcSi 41 with axial protected galactose substituents. 


\section{Conclusions}

This short review deals with the synthesis of glycosylated metal (mostly Zn) phthalocyanines which e.g., are potential reagents for photodynamic cancer therapy (PDT). The main starting materials for glycosylated zinc phthalocyanines are mono-, di-, and tetra glycosylated phthalonitriles of which the sugar part is e.g., glucose, galactose, lactose, cellobiose, maltose, and others. The synthesis of the glycosylated phthalonitriles is described. Then the transformation of these phthalonitriles into symmetrically and unsymmetrically mono-, tetra-, and octa- glycosylated zinc phthalocyanines is outlined. The sugars are attached either anomerically or via another of its $\mathrm{OH}$-groups to the phthalocyanine macrocycle.

Conflicts of Interest: The authors declare no conflict of interest.

\section{References}

1. Sharman, W.M.; van Lier, J.E. The Porphyrin Handbook; Kadish, K.M., Smith, K.M., Guilard, R., Eds.; Academic Press: New York, NY, USA, 2003; Volume 15, pp. 1-60.

2. Lyubimtsev, A.; Iqbal, Z.; Crucius, G.; Syrbu, S.; Ziegler, T.; Hanack, M. Synthesis of glycosylated metal phthalocyanines and naphthalocyanines. J. Porphyr. Phthalocyanines 2012, 16, 434-463. [CrossRef]

3. Hanack, M.; Schmid, G.; Sommerauer, M. Chromatographische Trennung der vier möglichen Konstitutionsisomere eines tetrasubstituierten Phthalocyanins am Beispiel von Tetrakis (2-ethylhexyloxy) phthalocyaninatonickel (II). Angew. Chem. 1993, 105, 1540-1542.

4. Hanack, M.; Crucius, G.; Calvete, M.J.F.; Ziegler, T. Glycosylated metal phthalocyanines. Curr. Org. Synth. 2014, 11, 59-66. [CrossRef]

5. Hanack, M.; Meng, D.; Beck, A.; Sommerauer, M.; Subramanian, L.R. Separation of structural isomers of tetra-tert-butylphthalocyaninatonickel(II). J. Chem. Soc. Chem. Commun. 1993, 58-60. [CrossRef]

6. Kobayashi, N. The Porphyrin Handbook; Kadish, K.M., Smith, K.M., Guilard, R., Eds.; Academic Press: New York, NY, USA, 2003; Volume 15, pp. 162-262.

7. Hanack, M.; Heckmann, H.; Polley, R. Methoden der Organischen Chemie (Houben Weyl), 4th ed.; Thieme Verlag: Stuttgart, Germany, 1997; Volume 9.

8. Kalz, W.; Homborg, H.; Küppers, H.; Kennedy, B.J.; Murray, M.S. Preparation and characterization of iscyanophthalocyaninatoferrates (III). Z. Naturforsch. Teil B 1984, 39, 1478-1489.

9. Phthalocyanines_Properties and Applications; Leznoff, C.C.; Lever, A.B.P., Eds.; VCH: New York, NY, USA, 1989-1996; Volume 1-4.

10. Rosenthal, I. Phthalocyanines—Properties and Applications; Leznoff, C.C., Lever, A.B.P., Eds.; VCH: New York, NY, USA, 1996; Volume 4, Chapter 13; pp. 486-514.

11. Kennedy, B.J.; Murray, K.S.; Zwack, P.R.; Homborg, H.; Kalz, W. Spin states in iron(III) phthalocyanines studied by Moessbauer, magnetic susceptibility, and ESR measurements. Inorg. Chem. 1986, 25, 2539-2545. [CrossRef]

12. Ben-Hur, E.; Rosenthal, I. The phthalocyanines: A new class of mammalian cells photosensitizers with a potential for cancer phototherapy. Int. J. Radiat. Biol. 1985, 47, 145-147. [CrossRef]

13. The Porphyrin Handbook; Kadish, K.M., Smith, K.M., Guiliard, R., Eds.; Academic Press: New York, NY, USA, 2003; Volume 19.

14. Lukyanetz, E.A.; Porphyrins, J. Phthalocyanines as photosensitizers in the photodynamic therapy of cancer. Phthalocyanines 1999, 3. [CrossRef]

15. Lukyanetz, E.A.; Nemykin, V.N. The key role of peripheral substituents in the chemistry of phthalocyanines and their analogs. J. Porphyr. Phthalocyanines 2010, 14, 1-40. [CrossRef]

16. Rosenthal, I.; Krishna, C.M.; Riesz, P.; Ben-Hur, E. The role of molecular oxygen in the photodynamic effect of phthalocyanines. Radiat. Res. 1986, 107, 136-142. [CrossRef] [PubMed]

17. Wagner, J.R.; Ali, H.; Langlois, R.; Brasseur, N.; van Lier, J.E. Biological activities of phthalocyanines-VI. photooxidation of 1-tryptophan by selectively sulfonated gallium phthalocyanines: singlet oxygen yields and effect of aggregation. Photochem. Photobiol. 1987, 45, 587-594. [CrossRef] [PubMed] 
18. Ben-Hur, E.; Carmichael, A.; Riesz, P.; Rosenthal, I. Photochemical Generation of Superoxide Radical and the Cytotoxicity of Phthalocyanines. Int. J. Radiat. Biol. 1985, 48, 837-846. [CrossRef]

19. Spikes, J.D.; Bommer, J.C. Zinc tetrasulphophthalocyanine as a photodynamic sensitizer for biomolecules. Int. J. Radiat. Biol. 1986, 50, 41-45. [CrossRef]

20. Maillard, P.; Guerquin-Kern, J.-L.; Momenteau, M. Glycoconjugated tetrapyrrolic macrocycles. J. Am. Chem. Soc. 1989, 111, 9125-9127. [CrossRef]

21. Alvarez-Mico, X.; Calvete, M.J.F.; Hanack, M.; Ziegler, T. The first example of anomeric glycoconjugation to phthalocyanines. Tetrahedron Lett. 2006, 47, 3283-3286. [CrossRef]

22. Ellis, G.P.; Romney-Alexander, T.M. Cyanation of aromatic halides. Chem. Rev. 1987, 87, 779-794.

23. Hanack, M.; Drechsler, U. An Easy Route from Catechols to Phthalonitriles. Synlett 1998, 1207-1208.

24. Iqbal, Z.; Lyubimtsev, A.; Hanack, M. Synthesis of Phthalonitriles Using a Palladium Catalyst. Synlett 2008, 15, 2287-2290.

25. Ribeiro, A.O.; Tome, J.P.C.; Neves, M.G.P.M.S.; Tome, A.C.; Cavaleiro, J.A.S.; Sera, O.A.; Torres, T. First phthalocyanine- $\beta$-cyclodextrin dyads. Tetrahedron Lett. 2006, 47, 6129-6132. [CrossRef]

26. Choi, C.-F.; Huang, J.-D.; Lo, P.-C.; Fong, W.-P.; Ng, D.K.P. Glycosylated zinc(II) phthalocyanines as efficient photosensitisers for photodynamic therapy. Synthesis, photophysical properties and in vitro photodynamic activity. Org. Biomol. Chem. 2008, 6, 2173-2181. [PubMed]

27. Alvarez-Mico, X.; Calvete, M.J.F.; Hanack, M.; Ziegler, T. A new glycosidation method through nitrite displacement on substituted nitrobenzenes. Carbohydr. Res. 2007, 342, 440-447. [CrossRef] [PubMed]

28. Alvarez-Mico, X.; Calvete, M.J.F.; Hanack, M.; Ziegler, T. Expeditious Synthesis of Glycosylated Phthalocyanines. Synthesis 2007, 2186-2192. [CrossRef]

29. Zorlu, Y.; Ermeydan, M.A.; Dumoulin, F.; Ahsen, V.; Savoie, H.; Boyle, R.S. Glycerol and galactose substituted zinc phthalocyanines. Synthesis and photodynamic activity. Photochem. Photobiol. Sci. 2009, 8, 312-318. [CrossRef] [PubMed]

30. Soares, A.R.M.; Tome, J.P.C.; Neves, M.G.P.M.S.; Tome, A.C.; Cavaleiro, J.A.S.; Torres, T. Synthesis of water-soluble phthalocyanines bearing four or eight d-galactose units. Carbohydr. Res. 2009, 344, 507-510. [CrossRef] [PubMed]

31. Liu, J.-Y.; Lo, P.-C.; Fong, W.-P.; Ng, D.K.P. Effects of the number and position of the substituents on the in vitro photodynamic activities of glucosylated zinc(II) phthalocyanines. Org. Biomol. Chem. 2009, 7, 1583-1591. [CrossRef] [PubMed]

32. Iqbal, Z.; Lyubimtsev, A.; Herrmann, T.; Hanack, M.; Ziegler, T. Synthesis of Octaglycosylated Zinc(II) Phthalocyanines. Synthesis 2010, 18, 3097-3104.

33. Ribeiro, A.O.; Tome, J.P.C.; Neves, M.G.P.M.S.; Tome, A.C.; Cavaleiro, J.A.S.; Iamamoto, Y.; Torres, T. [1,2,3,4-Tetrakis ( $\alpha / \beta$-d-galactopyranos-6-yl) phthalocyaninato] zinc (II): A water-soluble phthalocyanine. Tetrahedron Lett. 2006, 47, 9177-9180. [CrossRef]

34. Iqbal, Z.; Hanack, M.; Ziegler, T. Synthesis of an octasubstituted galactose zinc(II) phthalocyanine. Tetrahedron Lett. 2009, 873-875. [CrossRef]

35. Crucius, G.; Hanack, M.; Ziegler, T.J. Synthesis of Glycoconjugated Phthalonitriles for New Phthalocyanine-Based Photosensitizers. Carbohydr. Chem. 2015, 34, 263-302. [CrossRef]

36. Crucius, G.; Hanack, M.; Ziegler, T. Synthesis and characterization of [1,4-bis( $\alpha$, $\beta$-galactopyranos-6-yl) phthalocyaninato]zinc(II). J. Porphyr. Phthalocyanines 2013, 807-813. [CrossRef]

37. Iqbal, Z.; Lyubimtsev, A.; Herrmann, T.; Hanack, M.; Ziegler, T. Anomerically glycosylated zinc(II) naphthalocyanines. Tetrahedron Lett. 2009, 5681-5685. [CrossRef]

38. Iqbal, Z.; Lyubimtsev, A.; Hanack, M.; Ziegler, T. Synthesis and characterization of 1,8(11),15(18),22(25)tetraglycosylated zinc(II) phthalocyanines. J. Porphyr. Phthalocyanines 2010, 14, 494-498. [CrossRef]

39. Iqbal, Z.; Ogunsipe, A.; Nyokong, T.; Lyubimtsev, A.; Hanack, M.; Ziegler, T. Photophysics and photochemistry of octaglucosylated zinc phthalocyanine derivatives. J. Porphyr. Phthalocyanines 2012, 16, 413-422. [CrossRef]

40. Lee, P.P.S.; Lo, P.-C.; Chan, E.Y.M.; Fong, W.-P.; Ko, W.-H.; Ng, D.K.P. Synthesis and in vitro photodynamic activity of novel galactose-containing phthalocyanines. Tetrahedron Lett. 2005, 46, 1551-1554. [CrossRef]

41. Leng, X.; Choi, C.-F.; Lo, P.-C.; Ng, D.K.P. Assembling a Mixed Phthalocyanine-Porphyrin Array in Aqueous Media through Host-Guest Interactions. Org. Lett. 2007, 9, 231-234. [CrossRef] [PubMed] 
42. Lau, J.T.F.; Lo, P.-C.; Tsang, Y.-M.; Fong, W.-P.; Ng, D.K.P. Unsymmetrical $\beta$-cyclodextrin-conjugated silicon(IV) phthalocyanines as highly potent photosensitisers for photodynamic therapy. Chem. Commun. 2011, 47, 9657-9659. [CrossRef] [PubMed]

Sample Availability: Samples of the compounds are not available from the authors.

(C) 2015 by the author; licensee MDPI, Basel, Switzerland. This article is an open access article distributed under the terms and conditions of the Creative Commons by Attribution (CC-BY) license (http:/ / creativecommons.org/licenses/by/4.0/). 